\title{
DETERMINA DA VIABILIDADE CELULAR DE BACTÉRIAS LÁTICAS SUBMETIDAS AO PROCESSO DE LIOFILIZAÇÃO.
}

\section{Bruno Pinto da Silva'; Elinalva Maciel Paulo-}

1. Voluntário de Iniciação Científica, Graduando em Lic. Ciências Biológicas, Universidade Estadual de Feira de Santana, e-mail: brunoslv403@gmail.com

2. Orientadora, Departamento de Ciências Biológicas, Universidade Estadual de Feira de Santana, e-mail: elinalvamaciel@yahoo.com.br

PALAVRAS-CHAVES: Liofilização, bactérias láticas, refrigeração

\section{INTRODUÇÃO}

A técnica de liofilização caracteriza-se na conservação de micro-organismos por meio da dessecação rápida de culturas que se encontravam em estado de congelamento (COSTA et al., 2009).

O isolamento, identificação, conservação e uso de micro-organismo se caracterizam como prática imprescindível para o desenvolvimento de pesquisas, processos, e obtenção de produtos de interesse econômico. Para que se utilizem tais recursos, é necessário manter os micro-organismos viáveis (GIRÃO et al., 2004). Segundo Paoli (2005), a implantação e manutenção de coleções de culturas permitem a formação de estoques de cepas, que podem ser utilizadas experimentalmente em diferentes momentos.

O objetivo da preservação de uma linhagem não é somente conservar o estado inicial do micro-organismo evitando mutações indesejáveis, mas também alcançar a máxima preservação da vitalidade das células e o numero de células viáveis (PASSADOR et al., 2010).

\section{MATERIAS E MÉTODOS}

\section{Micro-organismos}

Foram utilizados isolados de bactérias láticas pertencentes à coleção de cultura de bactérias láticas do Laboratório de Microbiologia Aplicada e Saúde Pública (LAMASP). Os isolados utilizados foram: Lactobacillus plantarum MT01 que foi liofilizada em 2014 e que estava acondicionado em refrigerador para a realização deste trabalho.

\section{Determinação da viabilidade celular (PAULO, 2010)}

Foi retirado um tubo do refrigerador pesado $0,01 \mathrm{~g}$ e reidratado em $9 \mathrm{~mL}$ de solução salina tampão fosfato, deixado em repouso por 15 minutos, prosseguindo com as demais diluições para a realização do plaqueamento no Agar MRS. As placas foram incubadas a $30^{\circ} \mathrm{C}$ por $72 \mathrm{~h}$. A contagem das colônias foi realizada em placas que apresentaram entre 30 a 300 colônias. O resultado foi interpretado em unidade formadora de colônia por mL (UFC). 


\section{RESULTADOS E DISCUSSÃO}

Os resultados foram observados em três meses e são apresentados na tabela abaixo:

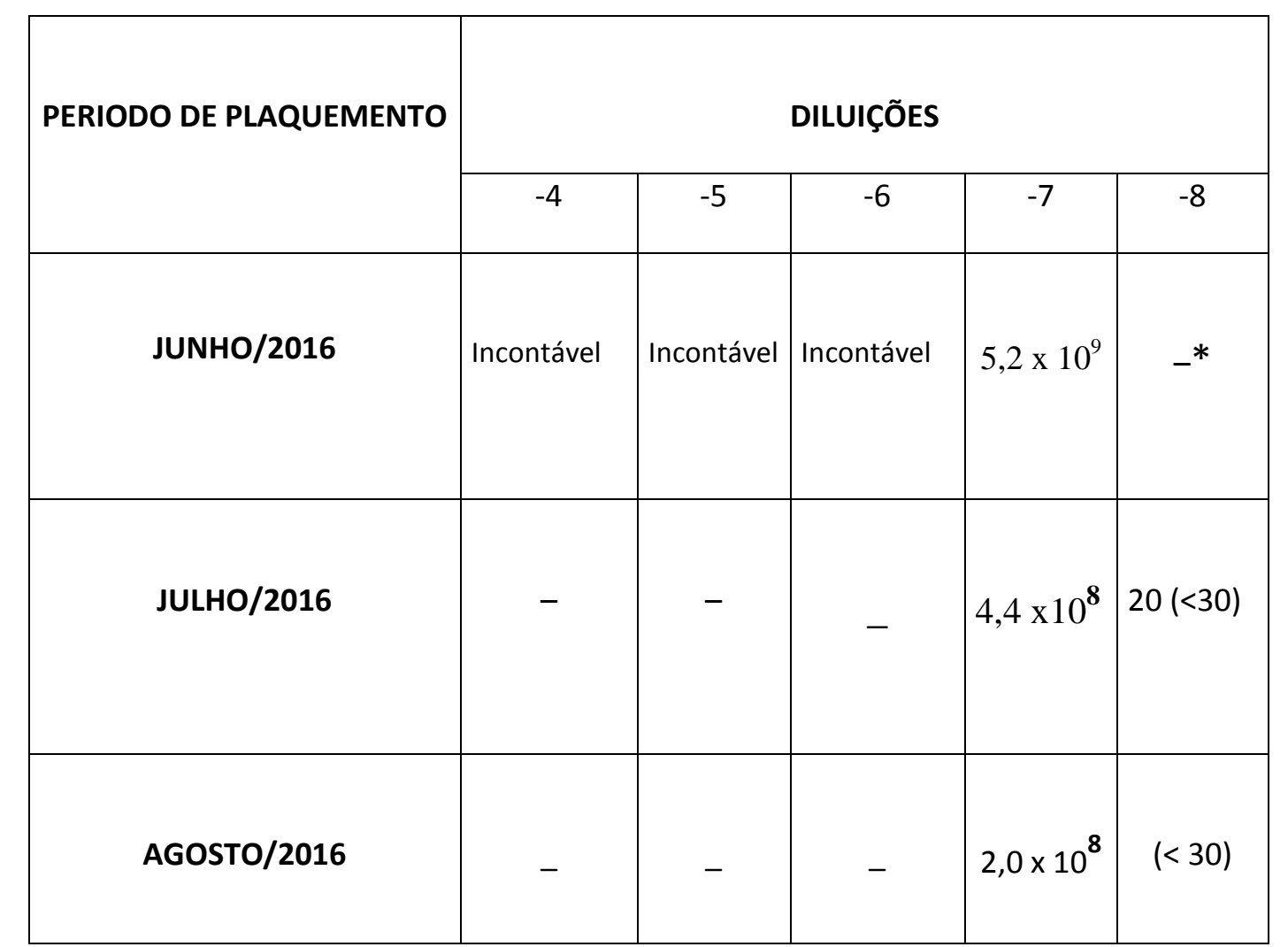

Contagem da UFC/g do Lactobacillus plantarum MT01 liofilizados em 25 de setembro de 2014.

(* plaqueamento não realizado)

Analisando os resultados percebe-se que houve um pequeno decréscimo na viabilidade célula das amostras liofilizadas que ficou acondicionada sob-refrigeração. Uma possível justificativa é que conforme Morgan et al. (2006) os procedimentos de estocagem e acondicionamento influenciam significativamente na vida de prateleira dos matérias liofilizados. Desta forma, os produtos liofilizados, armazenados em ampolas ou frascos de vidro, devem ser acondicionados em ambientes com baixa umidade, baixa temperatura, abriga de oxigênio, luz e contaminantes.

Com base no trabalho realizado por July Ane Barreto estagiária do LAMASP, que usou somente amostras bacterianas liofilizadas que ficaram acondicionadas em temperatura ambiente, foi possível notar um decréscimo notório da viabilidade celular, se comparado ao método de conservação combinado com a refrigeração usada no presente trabalho. Concluindo-se que é necessária uma combinação do método de liofilização com refrigeração ou congelamento para uma melhor viabilidade celular.

\section{CONCLUSÃO}


O resultado deste trabalho corrobora que o processo de liofilização é um método de conservação plausível, por preservar características de modo particular, fato que não acontece nas demais técnicas, porém, sugere-se que seja feito junto a outro método de conservação, a exemplo a refrigeração ou o congelamento.

\section{REFERÊNCIAS}

ABREU, M. M. V.; TUTUNJI, V. L. Implantação e manutenção da coleção de culturas de microorganismo do UniCEUB. Universitas: Ciências da Saúde, Brasília, v.02 n.2, p. 236-25, 2004.

BADIS, A.; LUDWIG, W;SCHLEIFER, K. H. Identification and technological properties of lactic acid bacteria isolated from raw goat milk of four Algerian races. Food Microbiology. V.21, n.2. 579-588, 2014.

COSTA, E. C.; TEIXEIRA, M. F. S.; DANTAS, T. V. M.; MELO V. S. P.; ARAUJO, S. A. C.; ROLIM, B. N. Princípios da estocagem e preservação de amostras microbiológicas. Ciências Animal, Goiânia, v.19, n.2, p.111-122, 2009.

DE MAN, J.C.; ROGOSA, M.; SHARPE, M.E. A medium for cultivation of lactobacilli. J. Appl. Bacteriol., 23, 130-135, 1960.

DELLARETTI, Érica Maciel. PRESERVAÇÃo DE FUNGos EM BAIXAS TEMPERATURAS. 2014. 36 f. TCC (Graduação) - Curso de Bacharelado Interdisciplinar em Biossitemas, Universidade Federal São João Del-rei, Sete Lagoas, 2014. Disponível em:

HTTP://www.ufsj.edu.br/portal2repositorio/File/cobib/monografia erica versao final .pdf. Acesso em 30 mar. 2015.

GIRÃO, M. D.; PRADO, M. R.; BRILHANTE, R. S. N.; CORDEIRO, R. A.; MONTEIRO, A. J.; SIDRIM, J. J. C.; ROCHA, M. F. G. Viabilidade de cepas de Malassezia pachydermatis mantidas em diferentes métodos de conservação. Revista da Sociedade Brasileira de Medicina Tropical, Rio de Janeiro, v.37, n.3, p. 229-233, mai/jun. 2004.

PAOLI, P. Biobancos microbiológicos a partir de coleta de amostras para a epidemiologia, diagnóstica e pesquisa. FEMS Microbiol Rev. v. 29, pg. 897-910, 2005.

PASSADOR, M. M.; PIRES, G. C. C.; FINATTI, D.; APARECIDO, C. C.; FIGUEIREDO, M. $B$. Manutenção da viabilidade e patogenicidade de culturas mantidas na micoteca “Mário Barreto Figueiredo". Biólogico, São Paulo, [online], v.72, n.1, p. 51-55, jan./jun., 2010. Disponível em: biologico.sp.gov.br/docs/bio/v72 1/passador.pdf. Acesso em 30 mar. 2015. 